\title{
Tourmaline occurrences within the Penamacor-Monsanto granitic pluton and host-rocks (Central Portugal): genetic implications of crystal-chemical and isotopic features
}

\author{
I. Ribeiro da Costa $\cdot$ C. Mourão $\cdot$ C. Récio $\cdot$ F. Guimarães • \\ I. M. Antunes - J. Farinha Ramos • F. J. A. S. Barriga • \\ M. R. Palmer $\cdot$ J. A. Milton
}

Received: 29 April 2013/Accepted: 5 March 2014

(c) Springer-Verlag Berlin Heidelberg 2014

\begin{abstract}
Tourmalinization associated with peraluminous granitic intrusions in metapelitic host-rocks has been widely recorded in the Iberian Peninsula, given the importance of tourmaline as a tracer of granite magma evolution and potential indicator of Sn-W mineralizations. In the Penamacor-Monsanto granite pluton (Central Eastern Portugal, Central Iberian Zone), tourmaline occurs: (1) as accessory phase in two-mica granitic rocks, muscovitegranites and aplites, $(2)$ in quartz ( \pm mica)-tourmaline rocks (tourmalinites) in several exocontact locations, and (3) as a rare detrital phase in contact zone hornfels and metapelitic host-rocks. Electron microprobe and stable isotope $\left(\delta^{18} \mathrm{O}\right.$, $\left.\delta \mathrm{D}, \delta^{11} \mathrm{~B}\right)$ data provide clear distinctions between tourmaline populations from these different settings: (a) schorl-oxyschorl tourmalines from granitic rocks have variable foititic component ( ${ }^{\mathrm{X}} \square=17-57 \%$ ) and $\mathrm{Mg}$ / $(\mathrm{Mg}+\mathrm{Fe})$ ratios $(0.19-0.50$ in two-mica granitic rocks, and $0.05-0.19$ in the more differentiated muscovite-granite and aplites); granitic tourmalines have constant $\delta^{18} \mathrm{O}$
\end{abstract}

Communicated by G. Moore.

Electronic supplementary material The online version of this article (doi:10.1007/s00410-014-0993-7) contains supplementary material, which is available to authorized users.

I. R. da Costa $(\bowtie)$ · F. J. A. S. Barriga

Departamento de Geologia, Faculdade de Ciências, Universidade de Lisboa, Lisboa, Portugal

e-mail: isabelrc@fc.ul.pt

I. R. da Costa · C. Mourão · F. J. A. S. Barriga

CREMINER/LARSyS (Laboratório Associado), Lisboa, Portugal

C. Récio

Servicio General de Análisis de Isótopos Estables, Universidad de Salamanca, Salamanca, Spain values $(12.1 \pm 0.1 \%$ ), with wider-ranging $\delta \mathrm{D}(-78.2 \pm$ $4.7 \%$ ) and $\delta^{11} \mathrm{~B}(-10.7$ to $-9.0 \%$ o values; (b) vein/ breccia oxyschorl $[\mathrm{Mg} /(\mathrm{Mg}+\mathrm{Fe})=0.31-0.44]$ results from late, $\mathrm{B}$ - and $\mathrm{Fe}$-enriched magma-derived fluids and is characterized by $\delta^{18} \mathrm{O}=12.4 \%, \delta \mathrm{D}=-29.5 \%$, and $\delta^{11} \mathrm{~B}=-9.3 \%$, while replacement tourmalines have more dravitic compositions $[\mathrm{Mg} /(\mathrm{Mg}+\mathrm{Fe})=0.26-0.64]$, close to that of detrital tourmaline in the surrounding metapelitic rocks, and yield relatively constant $\delta^{18} \mathrm{O}$ values $(13.1-13.3 \%)$, though wider-ranging $\delta \mathrm{D} \quad(-58.5$ to $-36.5 \%)$ and $\delta^{11} \mathrm{~B}(-10.2$ to $-8.8 \%$ ) values; and (c) detrital tourmaline in contact rocks and regional host metasediments is mainly dravite $[\mathrm{Mg} /(\mathrm{Mg}+\mathrm{Fe})=$ $0.35-0.78]$ and oxydravite $[\mathrm{Mg} /(\mathrm{Mg}+\mathrm{Fe})=0.51-0.58]$, respectively. Boron contents of the granitic rocks are low $(<650 \mathrm{ppm})$ compared to the minimum B contents normally required for tourmaline saturation in granitic melts, implying loss of B and other volatiles to the surrounding host-rocks during the late-magmatic stages. This process was responsible for tourmalinization at the exocontact of the Penamacor-Monsanto pluton, either as direct tourmaline precipitation in cavities and fractures crossing the pluton margin (vein/breccia tourmalinites), or as replacement of mafic minerals (chlorite or biotite) in the host-

F. Guimarães · J. F. Ramos

Laboratório Nacional de Energia e Geologia (LNEG),

Săo Mamede de Infesta, Portugal

I. M. Antunes

Escola Superior Agrária, Instituto Politécnico de Castelo Branco, Portugal, Geo-Environmental and Resources Research Center (CIGAR), University of Porto, Porto, Portugal

M. R. Palmer · J. A. Milton

School of Ocean and Earth Science, University of Southampton, Southampton SO14 3ZH, UK 